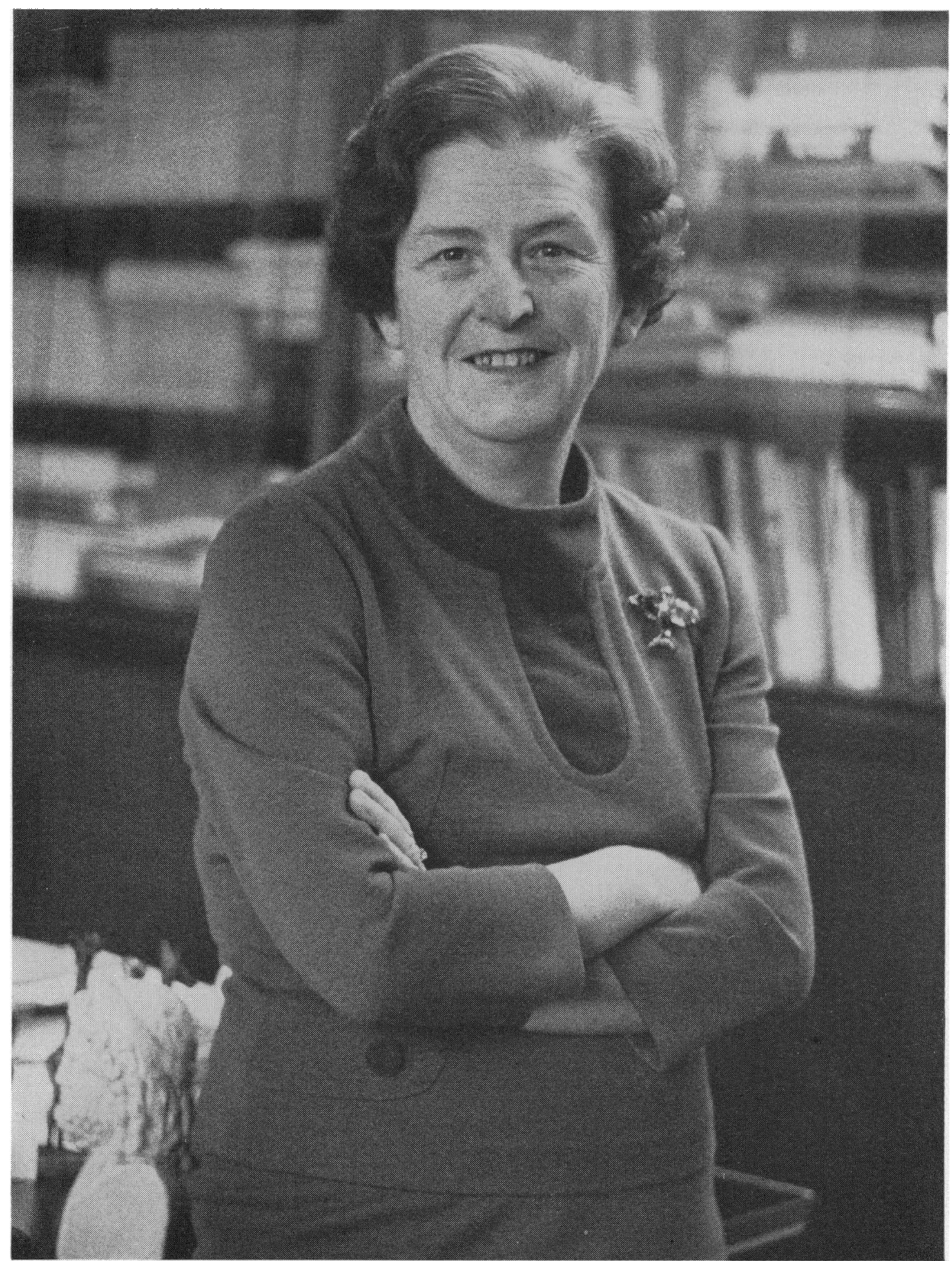

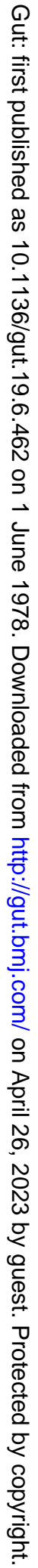

Professor Dame Sheila Sherlock

Godfrey Argent 


\section{Professor Dame Sheila Sherlock}

Sheila Sherlock received her medical education in Edinburgh, where her student career was brilliant. She qualified in 1942 and had had to work extremely hard coaching other students to pay her way through the course. In addition to this tremendous effort, she helped to sustain her mother whose income was frugal. Her brilliance was combined with singular personal charm and, surrounded by many friends, she came to the notice of that exacting task-master Professor James Learmonth. She finished her undergraduate career as the most brilliant student and Ettles Scholar of the year 1942. On the recommendation of Professor Harold Scarborough she visited Hammersmith Hospital when I was in charge of the Medical Unit and expressed an interest in coming to work there. In due course we had to take up her references and I remember well the decisive letter from James Learmonth who was a fellow Scottish village schoolmate: 'Dear Jack, if you get Sheila Sherlock as your house physician you will be darned lucky'.

It was wartime and she quickly showed her capacity not merely to be a first-class doctor but also to have a tremendous dynamic urge towards research. 'Catarrhal jaundice' was an enormous problem among the troops, especially in North Africa, and also post-transfusion jaundice was beginning to be recognised. The nature of the condition had been largely guess-work and I had already embarked on liver biopsy to understand more clearly the nature of the problem.

Thus began Sheila's interest and development of her skill in the analysis of liver disease. She returned to Edinburgh in 1944 but within a year she had been awarded a Beit research fellowship, holding which she returned to work at Hammersmith. She extended her technical skills in analysing liver disorders by using the bromosulphophthalein method of estimating hepatic blood flow by catheter sampling from the hepatic vein. This added a new dimension to her researches and very quickly she was recognised as a future leader of great potential. She was awarded a Rockefeller travelling fellowship in 1947 and spent a year in Yale where she established many contacts with other leaders in liver studies. She contributed substantially to the interchanges between the United States medical schools and Hammersmith, which developed strongly following this period.

When the second world war ended we were inundated with large numbers of mature British trainees who had seen strenuous military service but also many who would be returning to other countries, particularly South Africa, Australia and New Zealand, and Canada. We appointed Sheila as a lecturer in medicine and consultant physician, giving her full charge of a medical ward. She was then aged 28 and our confidence was fully justified by her growing renown and her gifts as a teacher who could hold the interest of many postgraduates senior to herself in age. Her dynamic energy never flagged and in the intervening three decades her reputation and leadership have never been challenged. 
She has had many firsts. She was the youngest woman physician to be elected to the Fellowship of the Royal College of Physicians. In her Edinburgh days women were not admitted to the two centuries-old Royal Medical Society. Sheila was the first to break into this male preserve when invited to lecture there to a crowded house. A whole string of awards came her way from all the specialist associations dealing with liver disorders and, indeed, with gastroenterology. She remained an academic physician in the department of medicine at Hammersmith for 11 years from 1948 to 1959, after which she was appointed professor of medicine at the Royal Free Hospital. During her period at Hammersmith the accommodation in the department of medicine was extremely cramped, affecting all our staff. There were restrictions on the numbers who could be promoted into higher academic ranks and Sheila's laboratory was invariably crowded even beyond its maximum capacity. She was well trained therefore in 'making do' with inadequate space and, while holding the chair at the Royal Free Hospital on its now abandoned old site, she had to establish her own laboratory in a hut on the roof approached by a variety of step-ladders! 'Nil desperandum', she achieved a continuation of her development with a well-selected core of staff and a multitude of brilliant young visiting researchers who came to work with her. Most of these are now moving on into senior positions in teaching hospitals and to chairs of medicine in the English-speaking world. It was deplorable that the Royal Free and many other leading academic medical units were housed in totally inadequate quarters, but all now rejoice that, at least, the Royal Free Hospital has been relocated and rebuilt. Thus in the last year or two Sheila has found herself at last with space, accommodation, and equipment in harmony with her position as a leader of British and, indeed, European medicine. High positions have come her way, Presidencies of international societies, Senior Censor and Vice-President of the Royal College of Physicians, honorary fellowships of the American College of Physicians and of the Royal Canadian College of Physicians, together with many other recognitions.

Sheila commutes across the Atlantic to maintain her international contacts, which carry many responsibilities. Her relationships with and acquaintance with the leaders of world medicine have been enormously beneficial to this country.

She has combined her successful career in academic medicine with a happy domestic life as a wife and mother. Her husband, D. Geraint James, is an active consultant physician and an enthusiastic teacher and organiser of medical societies. Strongly extroverted, he maintains a wide range of contacts extending beyond the academic circle. Together they have brought up two daughters and they run a most hospitable household where overseas visitors are so frequently welcomed and entertained.

Sheila's personality is one of enjoyment of life. She enjoys her work, she enjoys teaching, she enjoys tackling clinical problems. She rises to every occasion and fits the posts offered to her so frequently with meritorious accomplishment.

She has published hundreds of papers on every facet and consequence of liver disease, including cerebral and renal complications and the associated metabolic disorders, immunological and viral factors. Generous and loyal to her associates, she remains her charming modest self and is perhaps the most outstanding and exemplary leader in British university medicine today. 